\title{
The Personality Analysis of the Steady and Stable Educators in MAN 1 Medan
}

\author{
Nurkholidah $^{1}$, Saiful Akhyar Lubis ${ }^{2}$, Syamsu Nahar ${ }^{3}$ \\ ${ }^{1,2,3}$ Universitas Islam Negeri Sumatera Utara, Indonesia \\ lubis.ckolidh123@gmail.com
}

\begin{abstract}
This study aims to describe the steady and stable personality of educators in MAN 1 Medan. This research is a field research and the research approach used is a descriptive qualitative research approach. In this study, the research background chosen was personality competence in MAN I Medan. Personality competency research focuses on a stable and stable personality. The background of this research is natural. To obtain valid data on the topic being researched, observation, interviews, and documentation are used. The credibility or validity of the data in this study uses triangulation techniques. The triangulation technique in this study used source triangulation and technique triangulation as a way to determine the credibility of the data. The results showed that educators at Madrasah Aliyah Negeri 1 Medan had steady and stable personalities, as evidenced by their respect for differences in ethnicity, gender, responsibility for their duties, pride in being teachers, and continuous self-development, close to God, work ethic. Based on the intention of ukhrawi not solely to be enjoyed, educators act in accordance with religious, legal, social and cultural norms. It is proven that educators at Madrasah Aliyah Negeri 1 Medan carry out the principles contained in the Pancasila ideology as a basis for acting and thinking for all Indonesian citizens with a sense of unity and unity.
\end{abstract}

Keywords personality, educator, steady, stable

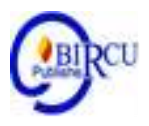

\section{Introduction}

Personality competence is one type of competency that teachers need to master, in addition to the other 3 types of competence: social, pedagogical, and professional. In the explanation of Government Regulation No. 19 of 2005 concerning National Education Standards, it is stated that teacher personality competencies are personality abilities that are: (1) steady; (2) stable; (3) adults; (4) wise and prudent; (5) authoritative; (6) have a noble character; (7) become role models for students and society; (8) evaluating own performance; and (9) self-development in a sustainable manner.

The character of students will be formed when a teacher also has a character according to Islamic values. The character of a good educator or also called a teacher's personality has Islamic characteristics that can be a role model for his students. Therefore this becomes very important internalized by educators because many educators think that after graduating from college or having been certified or when teaching it seems as if the task of learning to develop the personal abilities of the educator has stopped.

In line with the times, the moral and moral decadence of students has decreased, many cases have happened to the world of education, and strangely these accusations are often 
directed at educators with various claims ranging from low quality, unprofessional to the desire to close educational institutions. Therefore, educators must have a personality that will bring students to good morals. Because it may be that the demand for personality as an educator is sometimes felt to be very heavy compared to other professions. Because there is a popular saying in Indonesia that Guru is 'diguguized and imitated'. Digugu means that the messages conveyed by educators can be trusted so that they become a guide in living life.

In other words, the most important thing that an educator must do in an effort to shape the personality of his students into a noble person, first an educator must be able to make himself someone who can be digested and imitated. It is not appropriate for an educator who invites kindness to students, but he himself cannot be an example of that kindness. Related to that, Allah SWT, insinuated loudly with His words:

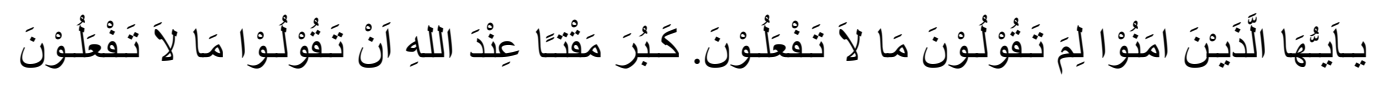

O you who believe, why do you say what you did not do? There is so much hatred with Allah that you say things that you don't do.(Qs. As Shaff [61]: 2-3)

In this verse Allah swt strongly criticizes people who are only good at speaking but who do not act. Then in Islamic education between students and educators have a strong relationship (relationship). According to Syamsu Nahar, the relationship between students and educators in general can be summarized into three parts. First, students must find and select educators who truly have qualifications as educators. Second, for a student, he must have the confidence that an educator has a degree of perfection and will never fade even though it is known that the educator has an attitude and / or behavior that is not praiseworthy. And third, a student should always respect the educator in any situation, because respect is done because of the knowledge possessed by the educator / teacher.

Therefore, in building relationships between educators and students in learning, educators are the most decisive figures. Because apart from being a teacher, an educator is also a source of exemplary. Both in terms of behavior, science, and personality. This means that the responsibility of educators, is not only to provide knowledge and understanding for students, but as inspiration for students in saying, behaving, and acting / behaving. Therefore, in this position, an educator must have various competencies. Not only mature from the intellectual side, but also mature from the emotional side so that educators are truly able to become an oasis of life who is able to provide solutions to the problems experienced by their students (Nahar and Suhendri, 2020: 105-106).

This phenomenon shows that the morality of educators is still far from expectations. This can be seen in the teaching and learning process in the classroom. Many teachers lack discipline, such as being late in class, smoking in class, leaving early and not having learning tools.

This personality competency problem attracts researchers to conduct research at Madrasah Aliyah Negeri 1 Medan. Actually there are still many Madrasah Aliyah in Medan, for countries such as MAN 2, MAN 3 and MAPN 4, but researchers chose MAN 1 because according to researchers it has its own peculiarities. As for the distinctiveness of MAN 1, it is the best madrasa in Medan. According to records that this madrasa was started in 1983, there have been many achievements, ranging from sports, learning and religion. This achievement is inseparable from the competencies possessed by the teachers of MAN 1, the focus of this study is the personality competencies of teachers who are steady and stable. 
The many achievements are inseparable from the coaching carried out by educators who have good enough dedication and competence, especially personality competencies. Educators with good personality competencies must be at the forefront of efforts to improve education quality. MAN 1 Medan does not specify the personality competency standards that a teacher must have, the madrasah only explains in general that teachers must have noble morals.

\section{Review of Literatures}

\subsection{Definition of Personality}

Personality is a dynamic organization within the individual as a psychophysical system that determines his unique way of adapting to the environment (Allport, 1950: 23). Personality is an integration of the id, ego and super ego (Freud, 1993: 45). Personality is an integration of ego, personal unconsciousness and collective unconsciousness that gives birth to behavior (Jung, 1990: 12). These are some of the definitions of personality according to Western psychologists, in this case the Western psychologists differ in providing a definition of personality.

Of all the definitions of western psychological personality theory that have been stated above, there are different views of western psychological scientists in defining personality. However, from the overall definition, it can be concluded that personality is influenced and shaped by the environment in which humans interact and experience life. Thus, western psychology scientists are of the view that what shapes or influences human personality is the environment in which they live and their life experiences.

Then according to Muslim philosophers, human personality has nothing to do with body shape, face, physical harmony and other things like that. Humans have privileges due to reason, while good or bad human personality is shown by his actions. Actions are activities carried out by humans in order to fulfill their physical needs and instincts. Human actions are closely related to their mafahim and cannot be separated. Meanwhile, mafahim is an understanding of facts / reality based on a certain basis which is believed to be information stored in the brain. As for the activities of fulfilling physical needs and instincts.

Islam has provided solutions to humans in realizing Islamic personality, namely by making Islamic creeds as a basis for thinking, on which all their thoughts are built and their understanding is formed in providing solutions to human actions that arise from physical needs and instincts with the laws of syara 'which emanated from the creed. Thus, everyone who thinks based on Islamic beliefs and their desires are returned to the Islamic creed, then that person has an Islamic personality.

\subsection{Organizational Culture}

Organizational culture is a set of assumptions or systems of beliefs, values, and norms developed in organizations that serve as guidelines for behavior for its members to overcome the problem of external and internal adaptation. Organizational culture is a pattern of beliefs and organizational values that are believed and imbued by all members in doing work as an appropriate way to understand, think, and feel about related problems, so that it will become a value or rule within the organization. This will encourage members of the organization to work harder and create work motivation. (Mangkunegara in Arif, 2019)

Organizational culture according to Rosie in Sihombing et al (2020) can be defined as an organization's "personality" which means something that is inherent in the organization, and can even be said of company assets. Jalal (2017) shows that organizational culture can be part of the key to leadership decision making and organizational achievement. Whereas 
Robbins \& Judge (2013: 547) argues that organizational culture is a shared meaning system shared by members of the organization together, and in this shared meaning system contains 7 characteristics of the essence of organizational culture

Term "Personality in the discipline of Psychology, more specifically personality psychology. One character who is often referred to in defining the word "personality" is Gordon W. Allport. According to him, personality is a dynamic organization within the individual as a psychophysical system that determines his unique way of adapting to the environment (Suryabrata, 1986: 240-241).Then what is the difference between "personality", "character", "character"? For Allport, character and personality are one and the same, but seen from different points of view. Character is identified with the attachment of norms and judgments to a person, while personality is more neutral and depicts what it is (Suryabrata, 1986: 240-241).Meanwhile, attitude is always related to object, while trait is not. "Trait" is almost always broader than attitude. The greater the number of objects subjected to "attitude", the "attitude" is more similar to "nature". "Attitude" usually provides an assessment (accept or reject) of the object at hand, while the nature does not (Suryabrata, 1986: 240-241). Implicitly, personality is then defined as an essential trait that is reflected in a person's attitude that differentiates him from others.

When the term "personality" is juxtaposed with "educator" or "teacher", then the person's perspective then experiences a shift from the perspective of psychology into education. Therefore, seeing and understanding the term "educator personality" which is the focus of this study the author does not refer to the perspective of psychology but to the notion of "educator personality" as stipulated in the Republic of Indonesia Law no. 14 of 2005 concerning Teachers and Lecturers chapter IV article 10 paragraph 1 and PP RI No. 19 of 2005 concerning National Education Standards Chapter IV article 28 paragraph 3 and Permendiknas RI No. 16 of 2007 concerning Academic Qualification Standards and Teacher Competencies which govern the qualifications and competencies of educators

In the Laws, Government Regulations and Ministerial Regulations related to the personality of educators as mentioned above, it is emphasized that the existence of educators must have competencies which include:

1) Personality competence

2) Social competence

3) Pedagogic Competence

4) Professional Competence

In the explanation of Government Regulation No. 19 of 2005 concerning National Education Standards, it is stated that teacher personality competencies are personality abilities that are: (1) steady; (2) stable; (3) adults; (4) wise and prudent; (5) authoritative; (6) have a noble character; (7) become role models for students and society; (8) evaluating own performance; and (9) self-development in a sustainable manner. In detail, these sub competencies can be described as follows:

1) A steady and stable personality has essential indicators: acting in accordance with the norm of law; act according to social norms; proud as a teacher; and have consistency in acting according to norms.

2) Mature personality has essential indicators: showing independence in acting as educators and having a work ethic as a teacher.

3) A wise personality has essential indicators: showing actions that are based on the benefit of students, schools and society and showing openness in thinking and acting.

4) An authoritative personality has an essential indicator: having a behavior that has a positive effect on students and having respected behavior. Noble morals and can be role models have essential indicators: acting in accordance with religious norms 
5) (faith and piety, being honest, sincere, helpful), and having behaviors that are emulated by students.

The teacher personality competency analysis in this study focuses on a steady and stable personality. In detail, the teacher's personality competence is described, steady means constant; firm; Strong Personality means having an immovable personality in order to carry out his duties properly, professionally and responsibly. Stable means steady; sturdy; not wavering. So a stable person is a strong personality.

\subsection{Personality Competencies in National Education}

Teachers as educators whose main task is teaching have personality characteristics that are very influential in the successful development of human resource development. The solid personality of the figure of a teacher will set a good example for students and society, so that the teacher will appear as a person who deserves to be "dignified" and "imitated". Teacher personality is the most important factor for the success of learning of students (Gultom, 2010: 3). Zakiah Darajat that the personality that is contained in a teacher will determine whether he is a good "education" and "coach" for his students, or will it be a destroyer or destroyer for the future of his students, especially for young students (elementary level ).

\subsection{Educator Personality According to the Al-Quran}

The ideal size and personality of an educator is highly dependent on the ability and intellectual experience. Good educators must have labor skills, namely educated or trained personnel with good habits, so that they are able to adapt to the subject of their students and it is not enough, even educators are required to have good morals as taught by the Prophet. Ahmad (1980: 54)states that Rasulullah is the figure of the educator, and the companions as the subject of the student who always captures the noble example in him, has good character, has knowledge and has virtue in all his movements. Al-Abrasyi (1970: 136-139) explains the characteristics that must be possessed by teachers in Islamic education, among others; zuhud, namely not prioritizing material, maintaining self-purity physically and spiritually, being sincere in work, loving forgiveness, a teacher is a father before he becomes a teacher, must know the character of students, must master the subject matter.

An educator has a very big role in shaping and molding their students, especially students who have no sense and are not yet mature. They will always pay attention and try to imitate what their educators are doing. Therefore, educators must be aware of their position in the view of their students, namely as a substitute for their parents or guardians, who will be held accountable before Allah SWT. As the Word of Allah SWT,

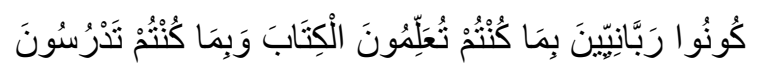

It means: "Be rabbani people, because you always teach the Bible and because you keep studying it. (QS. Al Imran: 79)

\subsection{Characteristics of Islamic Educators}

Everyone will get the real personality of an educator if they emulate the personality of the Prophet. The figure of the Prophet Muhammad who became a successful educator can be recognized not only in the Muslim world, but also from comments given by Western circles, such as Robert L. Gullick Jr. In Muhammad's book The Educator he states that Muhammad was an educator who guided people to greater freedom and happiness and gave birth to the order and stability that drove the development of Islamic culture, a revolution that had an unmatched tempo and a challenging passion. Only the superficial concept of education dared 
to deny its validity placing Muhammad among the great educators of all time. Education in the view of Islam is a conscious effort, structured and systematic to succeed the mission of human creation as servants and at the same time as khalifah of Allah on earth. The most distinctive characteristics of the Prophet are known to be shiddiq, fatanah, tabligh, and mandate. For that an educator must be able to imitate the Prophet Muhammad to find the personality of a Muslim educator.

\section{Research Methods}

This research is a field research and the research approach used is a descriptive qualitative research approach. In this study, the research background chosen was personality competence in MAN I Medan. Personality competency research focuses on a stable and stable personality. The background of this research is natural. This research was conducted at Madrasah Aliyah Negeri 1 Medan Jl. Williem Iskandar No. 9 b, Assistance Team, Kel. Siderejo Hilir, Medan Tembung District, Medan City, North Sumatra. The main data sources in qualitative research are words and actions, the rest are in the form of additional data such as documents and others. the source of the data in the study is the subject from which the data was obtained. When using interviews to collect data, the data source is called informants, namely people who respond or answer questions both in writing and orally. When using observation, the data source is in the form of objects, motion, or something processes. When using documentation, documents or records are the source of the data (Arikunto, 2002: 107). To obtain valid data on the topic being researched, observations are used while the researcher is in the field, the researcher makes observations on all activities related to learning and training carried out by teachers of MAN I Medan; researchers conducted interviews with the head of MAN I Medan, MAN I Medan, Deputy Principal, teachers and other components that support this research activity; Related to this, the researcher asked for permission from the Head of MAN I Medan, and related parties to document activities related to education and training activities. The credibility or validity of the data in this study uses triangulation techniques. The triangulation technique in this study uses source triangulation and technique triangulation as a way to determine the credibility of the data.

\section{Result and Discussion}

\subsection{A Steady and Stable Educator Personality in MAN 1 Medan}

Educators at MAN 1 Medan have a solid and stable personality. This personality can be formed if every time an educator carries out his duties, he always considers all his actions from all the aspects that surround him.Supriadi (2012: 65) suggests several tips to become a professional educator in terms of personality competencies, namely:

1) Trying to be a teacher who obeys the rules, such as arriving on time, dressed neatly and politely.

2) Shows a sense of empathy for students who are facing problems and have a high concern for helping them.

3) Show pride as a teacher with a display of teaching that is always fresh, excited and fun even though the teacher is having problems.

4) Show consistency in behaving in accordance with applicable rules.

5) Apply a compassionate approach in teaching.

6) Achievers that can be proud of students and the school.

7) Show sincerity in teaching and guiding students who are shown patiently answering every question, serving those who are in trouble, ready to help whenever needed. 
8) Trying to show exemplary behavior and actions that are commendable, such as being polite, friendly, smiling, outgoing, fair, honest, objective and empathetic.

Then according to Isjoni (2009: 86 ) personality competence is marked by:

a. Have good communication skills with students.

b. Have a creative and productive spirit

c. Have a work ethic and high commitment to the profession.

d. Always carry out continuous self-development through professional organizations, internet access, books, seminars and the like.

Some of the above theories, if examined carefully, are in fact very supportive of personality competence as stated in Permendiknas No. 16 of 2007 concerning Teacher Qualifications and competencies which are the main foundation of this research, it is explained that the personality competencies for classroom teachers and subject teachers are: Acting in accordance with the religious, legal, social and national cultural norms of Indonesia, including:

1) Respect for students without differentiating between beliefs, ethnicity, customs, area of origin and gender.

2) Act in accordance with the religious, legal and social norms that apply in society, and Indonesia's various national cultures.

With this theory, the steady and stable personality competence of educators can be proven by indicators: respecting students regardless of their beliefs, ethnicity, customs, area of origin and gender, acting in accordance with legal and social norms, being proud to be an educator and having the same patience high in facing various problems.

A stable soul was shown by the Prophet Muhammad, he said: "Really this heart is grieving and my tears flow because of your departure. But I will not say anything other than what Allah is pleased with." that is the sentence that came out of the mouth of the Prophet, when the death of his son Ibrahim. Then in another story, the Messenger of Allah saw a mother who was crying over the death of her child. Then Rasulullah saw, advised him to "be patient and seek the pleasure of Allah". With an angry tone, not realizing that it was the Prophet who was giving advice, then the woman replied: "You certainly don't feel what I feel." After realizing who the person advising her was, the mother immediately approached the Messenger of Allah, saying: " I did not know earlier that it was you who advised me, $\mathrm{O}$ Messenger of Allah. Then the apostle replied: "Patience was precisely the first incident".

What the apostle exemplified is a picture of a stable soul that is patient, calculating, full control of emotions. In his advice to the mother who had lost her child earlier, she explained that true patience is the ability to control emotional feelings from the very first moments of the test. If you pay close attention to the personalities of educators at Madrasah Aliyah Negeri 1 Medan, as previously explained, the findings of researchers through in-depth interviews both from individual teachers themselves and from leaders and students and strengthened by field observations are very suitable for this personality. Researchers directly observed the behavior of teachers who were calm enough to face the behavior of students in class who should be angry, but the teacher was still able to hold back his anger. This is the part of the teacher's personality who has the attitude of wara ', khauf, tawadhu' and patience.

Another indicator of a stable attitude is not discriminating between students, this can be proven by researchers in observations, for example when teachers give students the opportunity to ask questions and to provide input and opinions to anyone regardless of ethnicity and gender. Educators at MAN 1 Medan are very familiar with the concept of respecting differences in ethnicity, customs and gender. One of the educators when asked about the problem of respecting ethnicity and gender differences explained based on the word of God: 
يأيها ألناس إنا خلقنكم من ذكر و أنثى وجعلنكم شعوبا وقبآئل لتعارفوا إن أكرمكم عند ألله أتقكم إن ألله عليم خبير

It means: "O people, we actually created you from a man and a woman and made you nations and tribes so that you would know each other. Surely the most noble among you in the sight of Allah is the most devout among you. Allah is All-Knowing, All-Knowing. " (QS. Al Hujurat: 13)

In the above verse it can be understood that Allah Almighty, created humans from various ethnic groups and genders so that humans can get to know each other. The verse that readsabove at the same time explains the existence of gender differences as the creation and will of Allah Almighty, which must be respected, respected by all human beings according to their respective conditions. The principle of gender equality is an indication that Allah Almighty created humans in an equal or equal state, so that nothing is more than one another from the aspect of creation. In another verse Allah swt gives respect to humans without distinguishing humans. Allah says:

$$
\text { ولقد كرمنا بنى ءادم وحملنهم فى ألبر وآلبحر ورزقنهم من ألطيبت وفضلنهم على كثير ممن خلقنا تفضيل }
$$

Meaning: "And indeed We have glorified the children of Adam, We carry them on land and in the sea, We give them sustenance from the good and We enhance them with perfect advantages over most of the creatures that We have created." (QS. Al Hujurat: 13)

From the letter Al Hujurat above it can be understood that all humans come from the same process of events and in essence humans are "one family" which comes from Adam and Siti Eve (At Thobari, 1954: 512). As for the personality indicators that are steady and stable with the characteristics of behaving in accordance with the religious norms adopted, as personnel who are involved in madrasa institutions according to the observations of researchers, all educator behavior is adjusted to religious habits as the norms of Islamic teachings. According to Ramayulis, one of the main characteristics of teachers according to Islamic teachings is fear of Allah, as he said: "Some of the good qualities a teacher must have are as follows: Always fearing Allah is a quality that must always adorn a teacher. He always tries to maintain the mandate of knowledge that Allah has given him and does not betray this mandate with dirty behavior and behavior (Ramayulis, 2013: 59).

Educators are always muroqabah (closer to Allah), both openly and secretly. They protect it by reading the Koran after the obligatory prayers, sunnah prayers, sunnah fasting, remembrance, because they feel they need Allah in all their affairs and depend on Him and leave all their affairs and problems only to Him. The khauf nature of educators in this madrasa is a noble nature and is the nature of knowledgeable people, Allah Almighty praises the pious people who are always afraid of Him. Afraid if his deeds are not pleasing to him, afraid that his sins are not forgiven, afraid of slipping into the valley of sins, afraid that his words will hurt others. As Allah says:

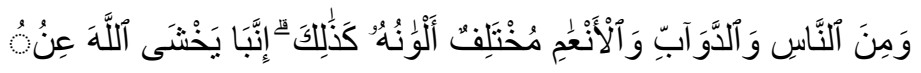

Meaning: "And likewise (also) among humans, reptiles and livestock are of various colors (and types). Indeed, those who fear Allah among His servants, are only scholars. Allah is Mighty, Most Forgiving.(QS. Fatima: 28) 
If these qualities (khauf, tawadhu ', wara') can always be maintained by every teacher, then it can be ascertained that the positive impact is very broad. Educators will avoid various disgraceful acts such as violence against students, even sexual abuse of their students, as what often happens and is reported in various mass media will completely disappear. The impact of the educators' khauf attitude in this madrasah which is also significant is that students will want to idolize teachers who have this praiseworthy nature and in the end, good generations and generations of educators who can be emulated will be born.

As for the responsible work ethic as a next characteristic, it only exists in educators who work on the basis of khauf (fear) of Allah SWT as a reflection of believers. The characteristics of a believer's character include work orientation not only because they want to show world achievements, but most importantly the achievement of ukrawi to get an assessment from Allah Almighty, as an achievement of worship to Him. The wise man said: "If a job is only intended for the world, it is like a person who plants grass, the result will grow grass. But if a good work is intended for ukhrawi, it is like planting rice, besides producing rice it also produces grass.

Among the responsibilities as educators is to deliver students to want and be able to carry out learning. The teacher provides guidance and direction and shows broad access to students so that they can gain broad knowledge and acquire various skills for the success of their learning (Hamalik, 2011: 127).

Regarding the responsibility of the Prophet, He said:

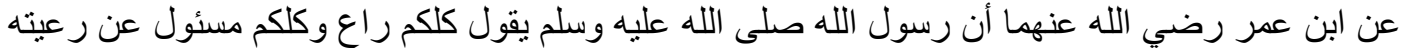

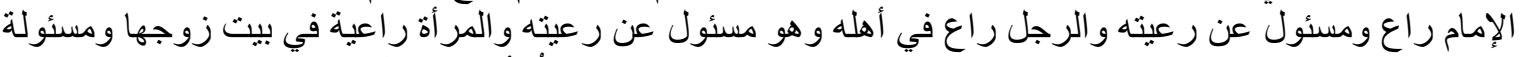

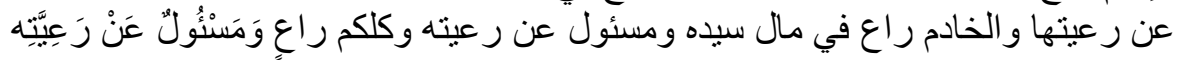

Meaning: "From Ibn Umar ra Verily Rasulullah Saw. Said: "You are the leaders, who will be held accountable. The ruler is the leader, and will be held accountable for his leadership. The husband is the leader of the family, and will be held accountable for his leadership. The wife is the leader in her husband's house, and will be held accountable for her leadership. Servants are leaders in managing their masters, and will be held accountable for their leadership. Therefore, you as a leader will be held accountable for his leadership". (HR. Bukhari Muslim)

The most basic thing that can be taken from the above hadith is that at any level, humans are leaders, including for themselves. Every action and action has a risk that must be accounted for. Everyone is a leader although at the same time everyone needs a leader when he has to face to face to create a solution in life where his abilities, skills and strengths are limited by the barriers that he creates himself in his position as part of the community.

Then the steady and stable personality traits at Madrasah Aliyah Negeri 1 Medan are also shown by efforts to develop themselves continuously as educators which are indicated by the desire to train themselves in utilizing various sources to increase knowledge / skills / and personality, participating in various activities that support the development of the teacher profession. , carries out various activities that foster reading and writing habits, develops and organizes activities that support the teaching profession. In terms of continuous and sustainable self-development, in addition to participating in training activities related to increasing teacher competence held by the Ministry of Religion / Ministry of Education and Culture, educators at MAN 1 Medan, the majority of whom have undergraduate qualification levels, are trying to continue to the Strata 2 level.

As Indonesian citizens who uphold the law, they obey the applicable laws in Indonesia and the prevailing social conditions in society. This can be proven by the fact that to this day 
no educator has dealt with legal issues. Related to the commitment of educators to the diversity of Indonesia's national culture, this is shown by holding arts and cultural performances and held once a year. In this art performance, students wear cultural clothing from various regions from Sabang to Marauke.

The sense of pride as an educator at Madrasah Aliyah Negeri 1 Medan is based on the achievements of this institution in various fields and events as described previously. The indicator of pride shown by educators with their participation in various activity events held outside the school is sufficient proof that they are confident in showing their identity to the community as school educators. Researchers can see deeper pride in educators from the reflection of high enthusiasm when they are invited to attend national celebrations such as the commemoration of the Republic of Indonesia's Independence Day and religious activities held by the government and other institutions. They feel proud to be educators at MAN 1 Medan by wearing the oversized educator uniform.

\section{Conclusion}

From the results of the research and the results of the data analysis that the researchers conducted on the analysis of the personality of educators at Madrasah Aliyah Negeri 1 Medan, the conclusion can be concluded that the educators at Madrasah Aliyah Negeri 1 Medan have steady and stable personalities, as evidenced by their actions respecting differences in ethnicity, gender, and responsibility. towards assignments, having a sense of pride in being a teacher, and continuous self-development, being close to Allah, the work ethic is based on the ukhrawi intention not only to be enjoyed. Educators act in accordance with religious, legal, social and cultural norms. It is proven that educators at Madrasah Aliyah Negeri 1 Medan carry out the principles contained in the Pancasila ideology as a basis for acting and thinking for all Indonesian citizens with a sense of unity and unity.

\section{References}

Ahmad, M.A.A. (1980). Turuq al-Tarbiyyah alIslamiyyah. Kairo: Maktabah al-Nahdlah alMishyyah.

Al-Abrasyi, M. A. (1970). Dasar-dasar Pokok Pendidikan Islam. Jakarta: Bulan Bintang. Allport, G.W. (1950) . The Nature of Personality. Gordon: Greenwood Publishing Group.

Arikunto, S. (2002). Prosedur Penelitian suatu Pendekatan Praktek. Jakarta: Rineka Cipta.

Arif, Syamsul. (2019). Influence of Leadership, Organizational Culture, Work Motivation and Job Satisfaction of Performance Principles of Senior High School in Medan City. Budapest International Research and Critics Institute (BIRCI-Journal), 239-254.

At Thobari. (1954). Jami’ al-Bayan fi Ta'wilil Quran. Kairo: Al Halabi.

Freud, S. (1993). Studies on Hysteria. New Jersey: Princeton University Press.

Gultom, S. (2010). Kompentensi Guru. Medan: Universitas Negeri Medan.

Hamalik, O. (2011). Proses Belajar Mengajar. Jakarta: Bumi Aksara.

Isjoni. (2009). Perkembangan Profesionalisme Guru. Pekan Baru: Cendikia Insani.

Jung, C.G. (1990). Psychologische Typen. Zurich: Rascher Verlag.

Kementerian Agama RI. (2011). Al-Qur'an Terjemahan Tafsir Per Kata. Bandung: CV. Insan Kamil.

Nahar, S. \& Suhendri. (2020). Gugusan Ide-Ide Pendidikan Islam Kh. Hasyim Asy'ari. Indramayu: Adab.

Ramayulis. (2013). Profesi dan Etika Keguruan. Jakarta: Kalam Mulia. 
Sihoming, T. et al. (2020). The Effect of Accounting Information and Organizational Culture on Decision Making. Budapest International Research and Critics Institute-Journal (BIRCI-Journal). P. 522-530.

Supriadi, D. et al. (2012). Komunikasi Pembelajaran. Bandung: Remaja Rosda Karya.

Suryabrata, S. (1986). Psikologi Kepribadian. Jakarta: Rajawali. 